\title{
Informational stocks and e-logistics management of a tourism company
}

\author{
Ioan Constantin Dima ${ }^{1}$, Alina Tenescu ${ }^{2}$, Petre Bosun ${ }^{3, *}$ \\ 1 University Valahia of Târgovişte, 35 Lt. Stanciu Ion Street, 130105, Târgovişte, Romania \\ 2University of Craiova, A. I. Cuza 13, 200585, Craiova, Romania \\ ${ }^{3}$ Technical University of Timişoara, Vasile Pârvan 2, 300223, Timişoara, Romania \\ *E-mail address: bosunpetre@yahoo.com
}

\begin{abstract}
The huge development of the Internet, the increasing number of users, low cost Internet access and cutting-edge connection technology equipment are forcing companies to adapt rapidly to ecommerce, and thus change the classic logistics process, including changes for logistics functions. Moreover, tourism companies feel this dynamic market and its flexibility, primarily due to the supply chain actors of touristic products - the tourists - who adapted themselves quickly to the new technological offers and already mastered web interfaces specialized in selecting and delivering travel packages. Moreover, their feedback is often instantly. Barely arrived at the destination they point out their opinions, send pictures in social networks, based on their own logistic type they have developed themselves. It is clear that tourism companies have to adapt to e- logistics, since they operate beyond tourism products themselves, primarily with informational products. A tour operator can develop destinations that can be managed in a stock that can be called informational stock. With this virtual component touristic product can be changed quickly depending on the feedback that requires this. Differentiation that occurs between e- touristic products stocks, informational stocks and classic tour packages stocks is required by their special cost management and their ability to change and adapt faster to the market. E-logistics required to adapt the supply chain process to the informational chain that leaves the point of origin and reach the end point to meet such customer requirements in this new medium of the Internet where the space or time notions have a new understanding and lose their normal dimension.
\end{abstract}

Keywords: m-logistics; inventory information; ERP; e-logistics; CRM

\section{INTRODUCTION}

The nowadays tourism activities compared to the 10 years ago processes, are clearly differentiated. Fantastic growth in the number of internet users, download / upload speed, Internet costs and specialized sites with performing search criteria developed by the search engines have led to a radical change in the sales chain management.

If in 1995 the number of internet users was only 16 million (http://www.internetworldstats.com/emarketing.htm), in March 2014 their number exceeded 2.9 billion. Not to mention download speeds and costs 10-15 years ago. Regarding the dynamic 
impact of web technology is sufficient to mention only the Internet took five years to achieve a target of 50 million users, compared to television or radio that took 13 years and 38 years, as Morgan Stanley report shows. It is easy to understand the major impact of the Internet on any commercial activity (Kordel, 2008; Molz, 2012; Borowski, 2014).

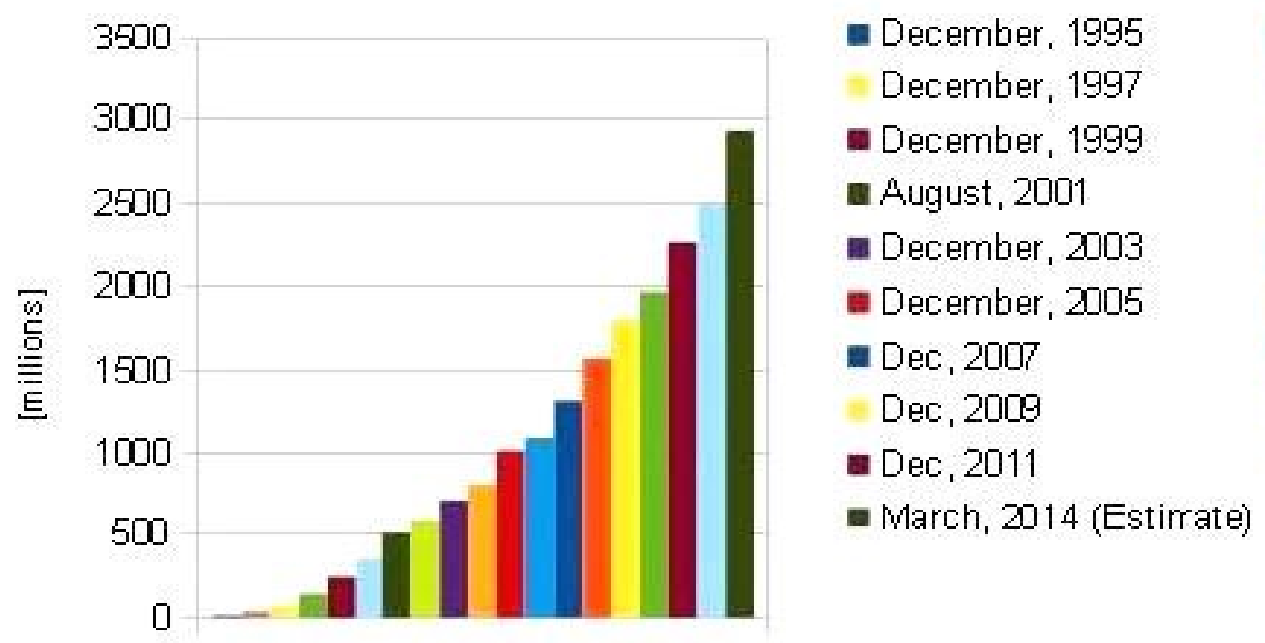

December, 1996

December, 1998

December, 2000

September, 2002

December, 2004

$=\mathrm{Dec}, 2006$

Dec, 2008

Sept, 2010

Dec, 2012

Fig. 1. Internet growth.

The outdated logistics customary, can keep their elegance, the slightly refined style, but their effectiveness is void in a market where the competitors understand to win and master the market in an electronic manner. The old logistics have to be taken by a new form of logistics where duality space time have different meanings. Tourism has emerged a new and unsuspected competitor a few years ago. The strongest partners / competitors for any travel agency in the market, have become even the tourists, because with a superior mobility, they adapted quickly to the new opportunities created and they have developed instantly their own e- logistics system, m-logistic already we can say, using powerful packages sales sites, online sales tickets sites, concert tickets, etc. While the tourists surpassed their initial e- logistics stage and are developing now their own m-logistic stage (based on mobile phones, tablets etc.), we can say that many operators in the tourism sector barely form their first e- logistics structures. If the difference between e- logistics and $\mathrm{m}$ - logistics is currently poorly discernible, we could see in a few years the advantage that m-logistics will gain over e- logistics due to its superior maneuverability, flexibility, speed of response and especially $24 / 7$ accessibility (Visser \& Yoshimoto, 2001; Karlin, 2002; Vlăduţescu \& Ciupercă, 2013).

Based on the classic logistics, defined by integrated planning, organization, execution and control of all flows of goods and materials along with related informational flows from suppliers and passing through value-added steps (i.e., production, distribution) to deliver the products to customers, including waste disposal processes and recycling issue, we note that elogistics involving tourism has obvious features implying another understanding of phenomena from the concept of stock and up to the ambiguous stage of the differentiation sometimes or overlap in other situations between information flows and touristic products flows (Dima \& Bosun, 1996; Vlăduţescu, 2013; Dima \& Man, 2013; Vlăduţescu, 2014). Sometimes in tourism we sell only information, without traditional stocks - something we can call them informational stocks without capital flows upstream of the sale. 


\section{STUDY ON THE ROLE OF E-LOGISTICS IN TOURISM}

Let's start with the simple scheme of classical logistics processes with the three components of logistics management: flows management, interfaces management and management of product support and pursue the role of e-logistics.

\section{1. Management of flows}

For a manufacturing company, the flows management divided simply : the natural, physical flow management, long time considered the vital segment of logistics processes and the information flows management. It was used the term "flux" to measure and assess quantitatively the intensity of processes as: number of pieces / unit time in a sector, how many trucks/unit time etc. Detached from the physical flows but with a trigger effect for these, the information flows analyze, rank and summarize information for the delivered products (competition, end users, feedback's, etc.) leading to follow short, medium or long term strategies.

Importance of logistics physical and information flows within tourism activities are reversed. Purely physical flows reduce their weight because tourism product itself has a lower physical component approaching more to the concept of information.

We analyze two situations commonly encountered in tourism.

Case A. A tour operator launches a circuit on a particular route. We can assimilate the touristic product itself, to its physical component, part of the flows management representing the transport, accommodation and additional services (travel insurance, meals, guide, optional services, etc.). But it becomes the product itself when it is accompanied by the cash flow from tour operator toward the provider of the logistics services. Not all services, especially the auxiliary services, have financial support, they can exist just as information and help selling the main product, receiving physical consistency only with the main product implementation and integration. A simple example in which a no-contracted ancillary service has only informational support and help marketing and selling basic product can be the following: in the previously tourist circuit, including an optional route to a destination with major tourism impact will be contracted only during the course of the trip depending on the availability of these additional services (i.e. organizing a gala last night in circuit, with music, dancing, contests and so on, or add for instance in a trip to Venice, at departure a stop in Lido di Jesolo, where tourists have available a few hours for beach and bath).

The effect is extraordinary, both variants are verified practically and creating a great atmosphere in the group. And now consider the physical consistency of the tourism product itself. Obviously, has not physical features permitting to be packaged and shipped in a conventional manner. Physical component exists only simultaneously with the informational attribute, because this is the peculiarity of the tourism product. Moreover, we can say that neither a contractual act does not bring an element of physical consistency because contracts are basically just for running frequent similar services (not in this specific case), often the only physical consistency is only the invoice issued by the service provider, on which runs payments and becomes a contractual liability.

The informational elements are embedded in the touristic product. We can say that if, hypothetically, we could eliminate the informational component of a touristic product, it remains mainly nothing. How to start, progress and sustain a tourism product?

Consider the case of a simple tourist circuit. Trigger: is there a period or a specific purpose for which to launch a touristic product? A day off accorded by the government or an opportunity 
arose at a certain destination may be the catalysts triggering market analysis for a new product launch. Through thiwer own information channels agencies gather data about product costs, attached ancillary services, book basic services and fix the rates and terms of payment. It follows product promotion, enrollment tourists, first financial flows from tourists to the agency.

At the option date the Agency shall analyze cash flows generated by the actual or estimated financial flows input FFI (cash from tourists) and next financial flows out FFO (output cash directed to providers). Only if the report is acceptable, the agency launches FFO to suppliers and we can say that the physical component of the product occurred. Otherwise, it only exists as information or as a potential product which although can generate FFI . Of course some theorists may consider touristic product exists from the moment of conception until its consumption, but we have to make the difference between finally touristic product and touristic product as information that still triggers financial flows, marketing, analysis activities, feedback, etc. Because otherwise we could define as touristic product any offer launched by an agency, no matter how many chances would achieve. If the report FFI/FFO is insufficient to justify to trigger FFO to service providers and agency may determine circuit cancellation. You can cancel so easy just because it has not a physical component. Now the product has only the informational component and cancellation before option data has no financial repercussion. It remains only the tourists opinion who already started FFI's and have to wait now for their returns. But now we are only interested in bodily appearance, the physical size of the touristic product, not for the logistics support. Since becoming touristic product, we can say that it enters directly in stock and it will be used later and managed separately in the inventory management. The problem could occur when the cost of inventories stock determin a negative ratio FFI $\mathrm{FFO}<0$. Because once inside the stock, in general, the product can remain in inventory management over the scheduled time consumption, logistics support is one that can rehabilitate an unfavorable product materialize.

Case B. Consider the case where a tour operator $\mathrm{T}$ contracted with a service provider $\mathrm{P}$, accommodations in guarantees rooms for an entire season following to sell on the market this summer touristic destination. In this case always appears a contract that stipulates the timing of payments and additional clauses. But even in this case, T will try to launch FFI flows in the period in which the product has no physical consistency, before the time the first payment is made, (payments are spread out over the season). I mean, $\mathrm{T}$ will try to sell a touristic product (there is only the informational support) by specific methods of sale: early booking discounts for special offers, various discounts, tourism fairs etc. From the first payment, so from the moment FFO starts the product added its physical consistency and start inventory management. Stock will not be just informational stock. The product appears in stock and logistics support is becoming essential. Complexity of managing this type of stock comes from the fact that its management is done in collaboration with other stocks management, for instance transport management (seats coach management). Rooms are double or triple with a finite, but variable in terms of the total seats for sale. Paxes in rooms could not be sold over the number of seats in coach on the series. $T$ is trying to achieve maximum profitability from the sale of the double rooms or triple (maximum number of beds in the rooms usually exceeds bus seats) and the number of tourists in the bus. The transport costs are fixed, so the number of tourists in a series have to be optimized. Classical mechanism of logistics could hardly cope this supply chain management and sales. E- logistics through its inventory management components, we could call these stocks even e-tourism stocks is more flexible, dynamic and well adapted to changes in sales strategy instantly. So in this case, we distinguish a period in the life cycle of the touristic product, when it only has an informational component, even if it generates FFI. 
Of course we can consider a touristic product as stock even that has only informational component, but we prefer to consider it in stock when it begins to generate cost management hitherto representing only a stock of information, whose management is also essential and is achieved by the E - logistics.

\section{2. Management of interfaces}

Relational management is used for setting interconnection networks for the products both with their internal environment and the external environment. It is found at the intersection of physical and administrative flows with the role of establishing distribution networks. An interface type can be considered an ERP system. An application of ERP ( Enterprise Resource Planning) is a software infrastructure that supports the management and coordination of the various structures, processes and flows in the company to achieve business objectives. Here elogistics shows its decisive importance. Interfaces with different processes within the enterprise, connecting them with each other, permanent record of their stage of project products or their existence only as trade information to their use, maintenance and feedback to support future products, along with logistics support, is a set of easy to follow processes screenings, controlled and corrected in time. After all, the role of these ERP systems is to involve "the best practices" specific for vertical of business, but also to allow them flexibility depending on the specific conditions of a dynamic market (Franklin \& Crang, 2001; Chaffey, 2007; Creţu, 2009; Dima \& Vlăduţescu, 2012).

The second interface is extremely useful in tourism - CRM (Customer Relationship Management) a software infrastructure with a set of strategies, policies and technologies for attraction, retention and customer loyalty. In a broader sense, CRM related activities including marketing, sales, financial and technical support in relation to customers, potential customers, suppliers and partners.

Characteristic for the tourism market is merging the two systems into one that keeps track of the whole process starting from suppliers to the ultimate consumer, permanent record of financial flows to email marketing campaigns, surveys, promotional materials distributed to tourists, other travel agencies etc . There are so oriented software interface for both internal processes for travel agencies and end-users: tourists, agencies retailers.

E- logistics definitely imposed itself in this section. More so, as most processes can be considered having an informational nature and treated as such. Almost everything is reduced to information in tourism. Depends how fast the information is accessed by consumers, how it is understood and appreciated and how is it related to other competitive information. The role of e- logistics is to adapt tourism products quickly and flexibly to market opportunities to support products through media campaigns. What are handled in these cases? Specifically, information! The tourism product is up to a certain point in its life cycle only information, and information has obviously its place on the internet and can be managed effectively only through e- logistics.

\section{3. Management of logistic support}

Logistics support classical refers to physical and informational flows that occur when disposing of products to retail service and post -sales processes. In tourism we believe that elogistics starts from the moment of the occurrence of stocks that we call informational stock even before their actual cost management. The role of e- logistics support is especially important, as the information may result in cancellation of stock in unfavorable cases for 
minimizing losses (Bajdor \& Grabara, 2014; Modrak \& Bosun, 2014; Grabara \& Bosun, 2014). In the same circuit we have been talking and admit that even before the option date, was given adequate support campaigning but for various reasons did not lead to the creation of a necessary tourists group. The reasons may be different, and not attributable to the business of e-logistics support: either appears a destination more attractive (i.e. cancellation of visas for a particular destination) or the emergence of a new competitor on the market with a strategy of severe domination regardless of cost (we meet in practice many such cases especially in tourism). In such unfavorable cases the tour operator may decide to cancel the circuit without financial losses, before the option data, minimizing expected losses as major losses by keeping inventory information and conversion into stock of touristic products. Of course e- logistics support must consider its own credibility for its customers and to try to quantify the value of this negative feedback so that e- logistics management can make the most appropriate decision (Stoica, 2004; Dima \& Vlăduţescu, 2012; Pintea, 2013; Katagiri, Takanashi, Ishizaki, Den \& Enomoto, 2013). A strong tour operator can continue the previous touristic product even if it takes a loss, just to respect its own authority in the market. Of course these unpleasant events should have a low frequency, or tour operator will remain only with credibility and we can only say that he lived and died pretty.

We believe that previous feedback's of e- logistics support are factors that contribute to the planning of tour operators to choose destinations, the duration of a touristic product and the types and costs of various tourist services embedded in the tourism product.

Besides their own tourist's feedback, online platforms with Reviews for destinations, accommodation is an excellent source for support logistics department.

Tourist's interest for sites with recommendations for travel is growing. Their connection with these sites works in two ways. On the one hand they read what other travelers mentioned about destinations they seek or even are searching for destinations if they do not have yet determined a vacation plan. Secondly, they participate in these Reviews, posting their own experiences and opinions about the places visited, hotels, attractions, restaurants, etc. And hence the explosion of these sites with a significant impact on supply chain even for tour operators who can make a selection of products based on the increased appetite of tourists for certain destinations. Beyond being an important source of inspiration for tourists, these sites may represent an important research aspect for travel agencies as it is a free marketing analysis, with a valuable general feedback (Borowski, 2013; Colhon, 2013; Smarandache \& Vlăduţescu, 2014; Avram \& Traistaru, 2014).

A study published by TripAdvisor site (specialized in travel reviews) in January 2013 states that $51 \%$ of tourists post reviews about their accommodation and $41 \%$ of them make their reviews known through emails or Facebook. A huge promotional channel is to be used in full.

According (http://info.text100.com/travel-tourism-digital-index-201) Text100 statistics show that $63 \%$ of tourists are influenced by family and friends; $55 \%$ of internet searches; 49 $\%$ of websites specialized in travel packages online; $33 \%$ use loyalty programs offered by service providers; $44 \%$ consult travel blogs; $37 \%$ check information on Facebook $22 \%$ use Pinterest.

A tour operator can not overlook the fact that the unconscious, tourists have created a mlogistics of their own, for purchase of tourism products through direct and fast access to the Internet.

We appreciate that tourists are even more dynamic and flexible than a tour operator, on the one hand due to the structure of agencies and tour operators - the size and internal organization - slower, slightly conservative, on the other hand also because tourists have gone 
already from e- logistics m-logistics. Their access to the Internet is no longer tied to a desk, a computer. Conversely, in the subway, on lunch breaks they access the internet and could form a very well defined image of destinations, prices, services, etc.

In a time when $4 \mathrm{G}$ technology impose, mobile equipment have amazing performance, tourists can not only quickly choose their destination, but may begin to influence other travelers through their postings and reviews from the time of consumption of the touristic product. Feedback is instantaneous because of the new developed tourist's m-logistics (Ericsson, 2000 ; Hristea \& Colhon, 2012; Tabără, 2012; Dascălu, 2014).

An eMarketer study (included only South Africa), dec.2013, shows an increase in mobile phone users with internet access reaching 4 of 5 users who accesses the Internet from mobile phones. eMarketer estimates that $73.4 \%$ of Internet users in 2013 accessed the Internet from a mobile device. This is set to rise to $79.1 \%$ in 2014 to reach $90.1 \%$ in 2017. Mobile Internet penetration (as a percentage of total Internet use) is the largest in the Middle East and Africa Africa (http://www.statisticbrain.com/facebook-statistics/)- (MEA), to a whopping $92.7 \%$ in 2013, forecast to reach $94 \%$ this year. Rates in Asia -Pacific is also very high - $83.9 \%$, rising to $87.41 \%$ this year (2014). Western Europe and North America have lower rates (because the number of PC in use is considerably higher than the MEA and Asia and the ratio PC / phone changes the rate), with $57.2 \%$ and $57.9 \%$ in 2013 , rising to $67.8 \%$ and $64.3 \%$ in 2014 .

Let's not forget the impact of social networks, tourists already have well-established habit to share their views on travelers reviews sections generally relevant. Regarding social media the impact is staggering. A statistical Facebook from $01 / 01 / 2014^{1}--$ looks incredible things: every 20 minutes 1,000,000 links are posted to events (share); 2,000,000 friend request and $3,000,000$ message transmitted. Atention: every 20 minutes! With a total of 1.31 billion active users of which 680 million mobile users accessing the Facebook, we can imagine the enormous force for penetration in every market, what effective marketing channel can be such a social network (Frunză, 2014; Vlăduţescu, 2013).

\section{CONCLUSIONS}

This adaptability applies not only to informational stocks but also for other stocks of tourism products because in this perimeter the component that has the greatest flexibility represents an important share. Let us not forget that one of the major goals of logistics is customer satisfaction. What extraordinary advantage has then e-logistics, that can modify elements of the product even during its consumption or in the worst case allowed to produce improvements for the next sales. Good informational inventory management, their efficient design and support may later turn them when informational stocks migrate to touristic products, in quality touristic packages that can satisfy as much as possible the requirements of end users. It is well known that a single tourist who schedules alone his holidays is less picky than tourists purchasing tourism products through an agency because the latter have higher expectations. Good informational stock management enables the e- logistics meeting these requirements.

Just adapting to the requirements of the current e- tourism, a travel agency can keep up with the dynamics and flexibility of tourists. Their mobility should be studied and used, trying to integrate logistics sustain processes on their common social media frequently visited. Even the planning of touristic products can source these social environments frequented by tourists. A social network like Facebook, well managed can be a real gold mine for a travel agency. 
Distinct peculiarities of informational inventories can leave a travel agency to change even important elements of their touristic product on the go, if the e- logistics functions are carried out effectively.

\section{ACKNOWLEDGMENT}

This work was partially supported by the grant number $33 \mathrm{C} / 2014$, awarded in the internal grant competition of the University of Craiova.

\section{References}

[1] J. Germann Molz (2012). Travel Connections: Tourism, Technology and Togetherness in a Mobile World. London: Routledge.

[2] Zdzisław Kordel, Geojournal of tourism and geosites 2 (2008) 137-139.

[3] Andrzej Borowski, International Letters of Social and Humanistic Sciences 14 (2014) 7-17.

[4] Petre Bosun, Vladimir Modrak International Letters of Social and Humanistic Sciences 14 (2014) 66-72.

[5] Johan Visser, Ryuichi Yoshimoto (2001). The Impact of e-Commerce on Transport. Tokyo, Japan: Faculty of Commerce and Management, Hitotsubashi University.

[6] Karlin J. G., Journal of Japanese Studies (2002) 41-77.

[7] Andrzej Borowski, International Letters of Social and Humanistic Sciences 14 (2014) $33-41$.

[8] Ştefan Vlăduţescu, Ella Magdalena Ciupercă (2013). Next Flood Level of Communication: Social Networks. Aachen: Shaker Verlag.

[9] Andrzej Borowski, International Letters of Social and Humanistic Sciences 3 (2013) 69-74.

[10] Ştefan Vlăduţescu, International Letters of Social and Humanistic Sciences 10(2) (2014) 100-106.

[11] B. M. Dascălu (2006). Germanitatea şi literele române. Bucureşti: Editura Fundaţia Culturală Ideea Europeană.

[12] I. C. Dima, P. Bosun (1996). Management Logistic. Bucureşti: Editura Didactică şi Pedagogică.

[13] Ş. Vlăduțescu (2013). Principle of the Irrepressible Emergence of the Message. Jokull.

[14] I. C. Dima, M. Man, Studia Universitas Petru Maior, Series oeconomica, Fasciculus 1 anul VI (2013).

[15] D. Chaffey (2007). E-Business and E-Commerce Management: Strategy, Implementation and Practice. Pearson.

[16] Ştefan Vlăduţescu (2013). Message as Fundamental Discursive Commitment of Communication. Journal. 
[17] Dumitru Vladut (1998). Figuri sintactice repetitiv-adjunctive In stilul stiinfific romanesc din secolul al XlX-lea. Filologie.

[18] Ioan Constantin Dima, Ştefan Vlăduţescu (2013). The Environment of Organizational Entities and its Influence on Decisional Communication. International.

[19] Creţu Ioana-Narcisa (2009). Introducere în ştiinţele comunicării. Note de curs. Sibiu. Editura Universităţii Lucian Blaga.

[20] Ştefan Vlăduțescu (2013). Three Diachronic Paradigms of Communication. International.

[21] A. Franklin, M. Crang, Tourist Studies 1(1) (2001) 5-22.

[22] D. S. Stoica (2004). Comunicare public. Relaţii publice. Iaşi, Editura Universităţii Al. I. Cuza.

[23] Ioan Constantin Dima, Ştefan Vlăduţescu (2012). Persuasion elements used in logistical negotiation: Persuasive logistical negotiation. Saarbrucken: LAP Lambert Academic Publishing.

[24] Katagiri Y., Takanashi K., Ishizaki M., Den Y., Enomoto M., Procedia-Social and Behavioral Sciences 97 (2013) 422-428.

[25] A. Pintea (2013). Intertextuality, Dialogism and the Social Construction of Journalistic Discourse. Studia Universitatis Petru Maior-Philologia, (15).

[26] Ştefan Vlăduţescu (2014). Eight Computational-Communicative Operations of Building Information. Mitteilungen Klosterneuburg

[27] Andrzej Borowski, International Letters of Social and Humanistic Sciences 3 (2013) 69-74.

[28] Ştefan Vlăduţescu (2013). A Completion to the Traditions Matrix-Standard - R. T. Craig, Induced by the Transformation of Communication-as-a-Field Membrane in Communication-as-a-Universe Membrane. American International.

[29] Marioara Avram, Aurelia Traistaru, International Letters of Social and Humanistic Sciences 13 (2014) 79-88.

[30] Ştefan Vlăduţescu (2013). The communication membranes. European.

[31] I. C. Dima, M. Man (2013). Considerations on the strategy for sustainable development of companies under the conditions of current globalization. Science Series Data Report.

[32] Andrzej Borowski, International Letters of Social and Humanistic Sciences 6 (2013) $86-90$.

[33] Ş. Vlăduțescu (2013). Principle of the Irrepressible Emergence of the Message. Jokull.

[34] Marian Siminică, Aurelia Traistaru (2013). Self-Directed Learning in Economic Education. International.

[35] Florentin Smarandache, Ştefan Vlăduţescu (2014). Neutrosophic Emergences and Incidences in Communication and Information. Saarbrucken: LAP Lambert Academic Publishing.

[36] Janusz Grabara, Michal Kolcun, Sebastian Kot (2014). The role of information systems in transport logistics. International. 
[37] Petre Bosun, Janusz Grabara, International Letters of Social and Humanistic Sciences 14 (2014) 59-65.

[38] Andrzej Borowski, International Letters of Social and Humanistic Sciences 4 (2013) 70-74.

[39] Colhon M. (2013). Automatic Lexical Alignment between Syntactically Weak Related Languages. Application for English and Romanian. In Computational Collective Intelligence. Technologies and Applications (pp. 266-275). Springer Berlin Heidelberg.

[40] Ştefan Vlăduţescu (2013). Message as Fundamental Discursive Commitment of Communication. Journal.

[41] M. Sălcudean (2009). Tudor Arghezi: discursul polemic. Iaşi: Institutul European.

[42] A. Gunasekaran, A. Ngai, W. T Eric, T. C. Edwin Cheng (2007). Developing an E-Logistics System: A Case Study. International.

[43] Aurelia Traistaru, Marioara Avram, International Letters of Social and Humanistic Sciences 13 (2014) 79-88.

[44] F. Buttle (2009). Customer relationship management: concepts and technologies. $2^{\text {nd }}$ ed. Oxford.

[45] Dag Ericsson (2000). E-Logistics - Key to Success in the Digital Economy. Athens: University of Skövde.

[46] Petre Bosun, Vladimir Modrak, International Letters of Social and Humanistic Sciences 14 (2014) 66-72.

[47] Andrzej Borowski, International Letters of Social and Humanistic Sciences 2 (2014) 110-121.

[48] Ştefan Vlăduţescu (2013). Three Diachronic Paradigms of Communication. International.

[49] Waralak Siricharoen (2010). Enhancing semantic web and ontologies for e-tourism, International.

[53] Rajesh K. Yadav, Nishant Dabhade, International Letters of Social and Humanistic Sciences 4 (2013) 49-69.

[54] Jacek Tittenbrun, International Letters of Social and Humanistic Sciences 11 (2013) $10-34$.

[55] Andrzej Borowski, International Letters of Social and Humanistic Sciences 2 (2014) 110-121.

[56] V. Tabără (2012). Dezvoltarea capacităţii administrative. Bucureşti: Editura CH Beck.

[57] Sandu Frunză (2014). Advertising and Administration under the Pressure of Ethics. Les Arcs: Editions de la Suers.

[58] Paula Bajdor, Iwona Grabara, (2014). The Role of Information System Flows in Fulfilling Customers' Individual Orders. Journal.

[59] Ştefan Vlăduțescu (2013). What Kind of Communication Is Philosophy? Jokull. 
[60] F. Hristea, M. Colhon (2012). Feeding syntactic versus semantic knowledge to a knowledge-lean unsupervised word sense disambiguation algorithm with an underlying Nä̈ve Bayes model. Fundamenta Informaticae.

[61] Andrzej Borowski, International Letters of Social and Humanistic Sciences 11 (2014) $1-168$.

[62] Ştefan Vlăduţescu (2014). From Personal and Social Relationships to Social Networks. International.

[63] B. M. Dascălu (2014). Echivocul imagologic în Caietele lui Emil Cioran. Studii de Ştiinţă şi Cultură.

[64] Aurelia Traistaru, Marioara Avram, International Letters of Social and Humanistic Sciences 13 (2014) 79-88. 